\title{
COMPETITIVENESS OF TRANSPORT COMPANIES IN THE OPINION OF STUDENTS
}

\author{
Jurgita Ginavičienè \\ Indrė Sprogytė \\ Vilnius College of Technologies and Design, Lithuania
}

\begin{abstract}
The paper presents the results of a quantitative research study carried out with 280 transport logistics students in Lithuania. The research focused on the students' opinion about the competitive advantage of Lithuanian transport companies. During their professional training, they filled out an electronic demographic data form online and evaluated the importance and attainability of the offered values on a 5-point Likert scale. The results revealed that when increasing the competitiveness of transport companies, the main attention should be paid to the customer - consumers, and their needs must be taken into account.
\end{abstract}

Keywords: competitiveness, consumer, student, transport company.

\section{Introduction}

Successful business is increasingly dependent on the company's management of the investment in people. Lithuanian transport companies revealed that consumers are forcing them to put more focus on competitiveness, to increase their market share, as well as to increase profits.

In today's world customers are increasing their demands desired goods or services. Product and services market is overcrowded and can meet virtually every customer's desire. Only companies that continuously improve consumer activities may compete in the market. Practically every transport enterprise to extent directs its activities to satisfy customer needs.

Logistics customer service should be understood implementation of mutually coordinated activities or logistics services affecting on customer satisfaction when is purchasing the product - the last act of process which usually starts by placing an order and ends delivery of the product to the customer (Wyrwicka et al.,2015).

From a logistical point of view, the end user suggests the final location of cargo reception, sets deadlines for deliveries and acquires title to the goods (Cyplik et al., 2008). Should be noted that these subordination of the company's activities to satisfy customer needs is reflected in practically every features implemented by the company. 
The aim of the paper is to analyze the competitiveness of transport companies by identifying students' opinions and their subjective experiences in their professional training.

The research methods used by the authors included a literature review and a questionnaire survey of transport logistics students conducted in 2014 - 2015 among transport companies in Lithuania.

In order to analyze the consumer's attitude towards transport companies and to assess the competitiveness-enhancing factors, quantitative research was used, which allowed the authors to explore students' opinions, as well as to identify the competitiveness-enhancing user related factors for transport companies.

\section{Theoretical aspects of fulfilling consumer needs}

Today, the consumer is in the spotlight of attention of many European Union Member States. This is reflected in the survey results carried out in various member states (European Consumer Satisfaction Management Guide, 2010). Nearly two-thirds of the members pointed out that the knowledge of the consumer is one of the most important factors. It is therefore clear that the consumer is also important for business itself.

Consumers will always want to get a high quality service that meets set expectations. If the customer, after the completion of service, is satisfied, then re-purchase becomes possible. One of the most important factors which shows the company's marketing strategy success is the fulfilment of the consumers' needs (Dudzevičiūtė \& Peleckienè, 2010).

A company of any nature, and especially those in the transport service sector must provide products and services to customers in order to implement their logistics strategy.

Main logistics strategy objectives:

- improvement of services, admitting that income depends on the level of logistics services provided;

- cost reduction by reducing the variable costs associated with transportation and storage;

- capital reduction to a minimum, reducing the investment in the logistics system and maximizing the return on assets of logistics.

A logistics strategy allows maintaining the highest level of customer service, despite the changes taking place in the company. This is especially relevant to companies supplying specific products or companies that provide services to special customers (Nedelescu- Ionescu \& Rujan, 2014). 
Empirical studies have shown that when the user is satisfied with the service received, his emotional attachment to the company becomes stronger (Perez et al., 2013).

The fulfilment of consumer needs in today's society under the current market economy dictates the tasks for the companies - to maintain the existing and attract new customers (Bivainis \& Zinkevičiūtè, 2006).

Due to the expanding global competition, new technologies came into use that improved the relationship between consumers and businesses, thus increasing customer expectations towards products and services. These changes in recent years have improved the satisfaction of users' needs. Businesses around the world are encouraged to look for ways to reduce costs, improve quality and meet the growing demands of consumers (Nedelescu- Ionescu \& Rujan, 2014).

Consumer's choice of purchasing a product (good or service) is determined by economic, political - legal, technological and demographic factors.

Consumer's behaviour - a behaviour related to the satisfaction of receiving service, which is sought, ordered, used, and disposed of, as well as the opinion formation about the delivery of the service. Consumer's behaviour change is formed with influence of various factors.

Consumer's behaviour change is mostly influenced by the search and evaluation costs (Zikienė \& Brazinskaitè, 2010). Karaliūtè \& Pilelienė (2012) and Palšaitis (2010) reveal that the factors influencing decision-making to purchase are: price, quality, and the service that is provided on time and in place (transport companies' services are no exception, due to untimely arrival of cargo, downtimes and additional expenses).

The organization must ensure that it will be taken care of the customer and other interested parties' needs and expectations. Factors such as health and safety, consumer traits, reliability, ergonomics and other factors important to customers must be evaluated. The management must ensure that the risks to customers are identified and reduced (Yaya et al., 2014).

Transport companies are no exception, therefore, the management must assess the consumer-related actions in order to improve their services. Customers of transport companies can be frustrated by inadequate services related to cargo delays, lack of information or other problems.

Services that do not meet the customers' expectations are evaluated $\mathrm{t}$ complaints. The main actions taken by the company to address customer complaints are development of instructions regarding addressing customer complaints and immediate measures and attendance at the customer's location to review and respond to the customer's complaints (Nabavi et al., 2014). 


\section{Transport company's competitiveness-enhancing factors}

In the process of globalization, a market economy leads to intensified competition among transport companies, as well as a more complex business environment.

Transport company's ability to ensure the meeting of needs of the customer, in coordination with other interested groups, increases its competitiveness.

Competitiveness manifests differently at different levels. The transport company in the chosen market is not the only one. Generally, other companies are striving to meet the same needs of the customer. In this way, there is a constant competition for the customer among the companies.

Each company's most important task (Pajuodis, 2005) is to satisfy the needs of targeted selective customers and make a profit. For this purpose, transport companies have established relationships with suppliers and analyse the customer needs in order to meet them best. The company has to investigate their microenvironment and, in accordance with the situation and the changes taking place in it, adopt and implement their marketing decisions.

Porter's five forces model allows us to describe the competitive environment (Virvilaite, 2012); its advantage shows through the concentration of separate businesses and products or production evaluation elements.

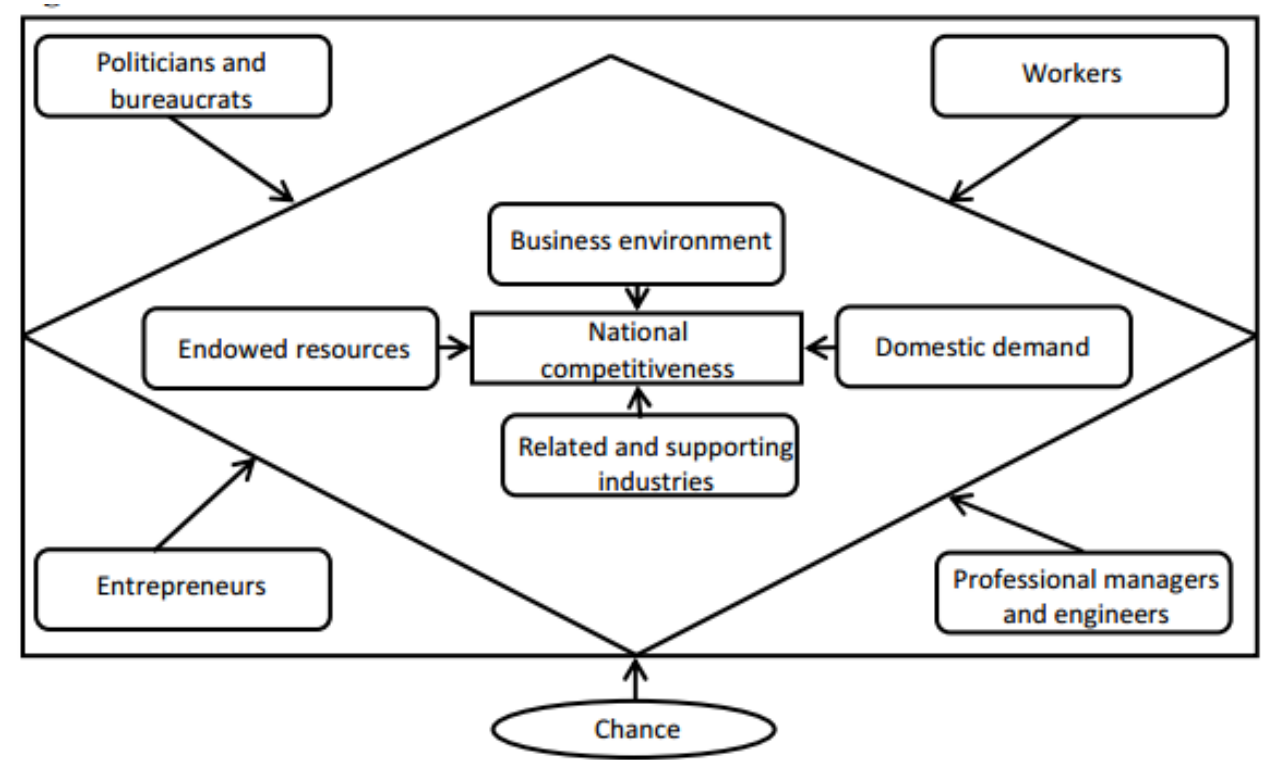

Figure 1 Nine-factor model (Balcarová, 2014)

Balcarová (2014) improved M. Porter's Diamond model and proposed a nine-factor model (Fig. 1), which can be used in practise in both developed and developing countries. As we can see in Figure 1, this model mainly analyzes the 
factors that influence competitiveness. The advantage of this model is that analyzing more factors provides a more accurate, targeted result.

The nine factors of the model can be used to figure out different professions' impact on competitiveness (Mitkutè \& Nagreckaitė, 2005). Thus, the analysis of competitiveness on the basis of the nine-factor model is necessary to thoroughly investigate both natural and human factors. It is an indepth analysis of these factors that allows us to identify what strongly influences the competitiveness. For example, the transport company's competitiveness determines the number of professional staff.

Transport companies affected by globalization processes tend to use temporary workers, who are often students. Temporary employment services Svedaite \& Ambras, 2013) contribute to the reduction of costs for businesses, and as a place for students' training, it promotes not only closer mutual communication and cooperation between the scientific and business sectors but also market-oriented practical learning for young people, adapting their theoretical knowledge acquired at a higher education institution.

Temporary work is useful for the student as well. The student gains experience, knowledge, the student's qualification is increased; it is easier for the student to find a job and he/she becomes more suitable to the labour market. It should be noted that the business and higher education sectors must focus on purposeful mutual cooperation. Nevertheless, in order to establish more efficient cooperation between business and science and to maintain a closer dialogue, it is stated that businesses are interested in the flexibility and control of labour relations, as well as in the reduction of unemployment among young professionals (Svedaite \& Ambras, 2013).

For this reason, the professional skills and expertise of youth are needed in order to increase the competitiveness of young people in the labour market and the company's success. Practical training is a tool that develops personal skills and theoretical knowledge as well as helps to implement and adapt it in the practical work environment.

It is important to promote and maintain effective cooperation between business and higher education institutions in pursuance of a successful resettlement of students into the labour market and their competent professional training.

An analysis of scientific sources showed that the transport company's factors that affect its competitive advantages are primarily the company's founders and executives who care about students as future workers in the market. Also, these companies continually analyze their suppliers, competitors and consumer expectations.

The analysis of scientific sources showed that the competitivenessenhancing factors, such as competitors and consumers. 


\section{Competitiveness of transport companies, based on the attitude of students as consumers}

The study took place in 2014-2015 during the practical training of students of Vilnius Technology and Design College, study programme Transport logistics, in transport companies. Three hundred and four students participated in the study.

Study sample - survey sampling bias is calculated according to the Paniott formula (Valackienè, 2004)

$$
n=\frac{1}{\Delta^{2}+\frac{1}{N}} ;
$$

where: $\mathrm{n}$ - sample size,

$\Delta^{2}$ - bias probability, bias.

$\mathrm{N}$ - target population, which ensures approximately a 5\% probability of

After the evaluation of the study sample bias, it was found that the minimum number of respondents was to be 174 students. The number of respondents was 280 students.

Data collection method - a questionnaire survey, which was carried out electronically, through www.apklausa.lt and sent to the students via their personal e-mails.

Questionnaire items were compiled structured, containing response options. Most issues have been concluded using the Likert scale, as more useful information for the investigation can be collected when responding to these types of questions.

The study was aimed to analyze the transport companies' competitive advantage in the students' opinion, as they were the customers and determined what impact on the competitiveness the consumer's attitude had.

First, the respondents were asked what the transport companies' competitiveness factors were. The question was formulated using the Likert scale, where 1 - not important at all, 2 - does not matter, 3 - partly important, 4 important, 5 - very important.

The respondents were (Fig. 2) to evaluate these criteria according to importance - is the customer satisfaction evaluated, are the competitors' activities analyzed, are additional services provided, is there focus on company's advertising, as well as are quality management systems introduced? 


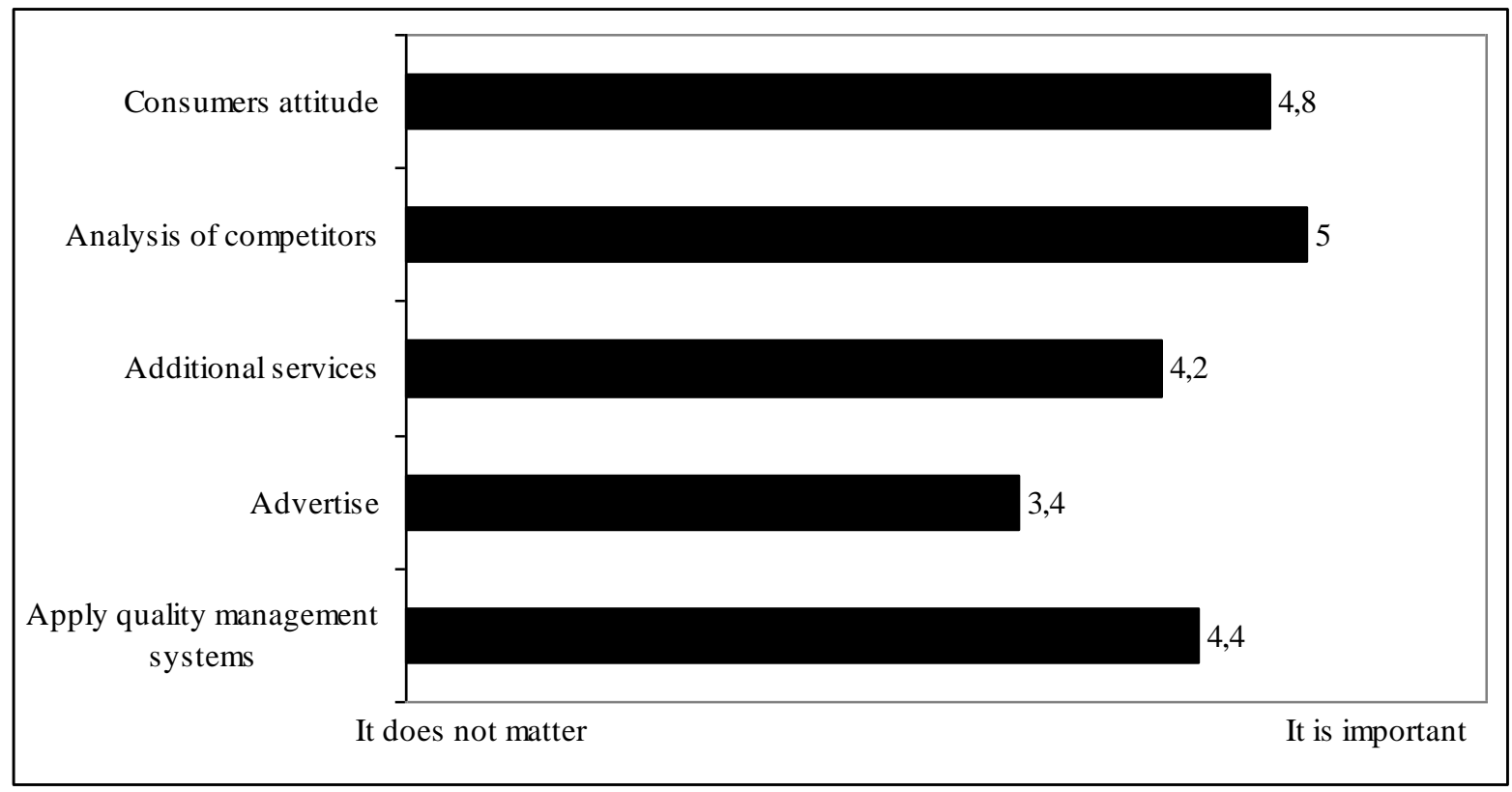

Figure 2 Factors of a transport company that increases its advantage (Ginavičienė \& Sprogytė, 2015)

The results showed that the most important competitive advantage enhancement criterion for the transport companies was an analysis of competitors (average $=5$ ) and a consumer satisfaction rating (average $=4.8$ ). A less important factor for transport companies was a strong focus on advertising. The total average rating was 4.36. Mode - 3, Median - 4 .

For this purpose, using the statistical program SPSS, Spearman's coefficient was calculated, the value of which showed a strong relationship between customer satisfaction assessment $(0.75>0.05)$ and the impact on the implementation of quality management systems and the analysis of competitors' activities. It revealed the transport companies' dependence on the competitiveness-enhancement advantage and relationship strength.

The respondents were asked to evaluate and compare the transport companies' activities and priorities (Fig. 3), in which their practical work was carried out, with other transport companies.

Most, i.e. $28 \%$ of the respondents stated that the company which they completed their training at, focused on continuous consumer surveys, and continuously responded to the comments received. Of them, $23 \%$ said that there was a continuous performance analysis of competitors and market monitoring. Not so much emphasis upon the transport company's internal environment, only $13 \%$ of the respondents indicated that their company had a team spirit. 


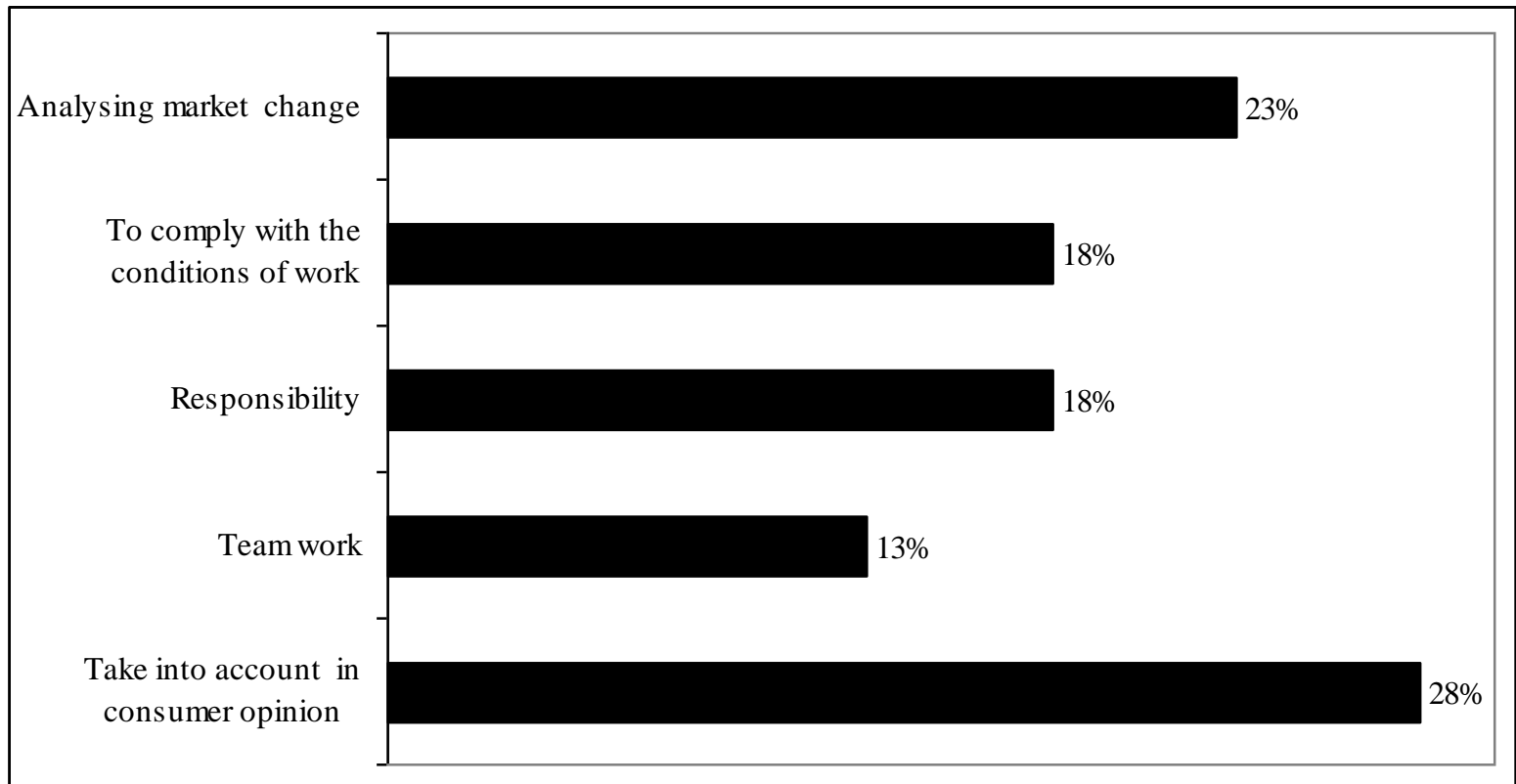

Figure 3 Criteria according to which the transport company compares its performance with that of its competitors (Ginavičienė \& Sprogytė, 2015)

Two criteria: there was strong dependence on specific skills of personnel and skilled workers, where Spearman's coefficient value was $(0.75>0.05)$, which suggests that the factors are related to each other and their relationship has a strong correlation.

In assessing the transport companies' success in the market, the respondents had to evaluate the time the service was provided in, the quality, competitive price, company name awareness, increase in the number of customers, as well as transport companies' approach towards consumers feedback from both existing and new customers. Fig. 4 provides data on the transport companies' success factors.

The question was formulated using the Likert scale, where 1 - not important at al, 2 - it does not matter, 3 - partly important, 4 - important, 5 - very important. Carrying out the works on time was found by the respondents as the major factor for a transport company. Of the respondents, $24 \%$ noted it. Consumer research and taking their comments into account was a very important factor towards the transport company's success. This criterion was specified by $20 \%$. In order to successfully operate in the transport market, according to $7 \%$ of the surveyed students, the company's name was important.

By applying the statistical program SPSS, Spearman's coefficient was calculated, which enabled the comparison of the factors and showed the strength of the correlation coefficient. The transport companies' competitivenessenhancing factors, such as complaints from former and current customers had strong dependence $(0.75>0.05)$ for the number of regular customers and the 
company's reputation. Not less important were the factors of dependence and the strength of the correlation coefficient $(0.95>0.05)$ in the price competitiveness and flexibility to carry out orders, as well as the quality of work.

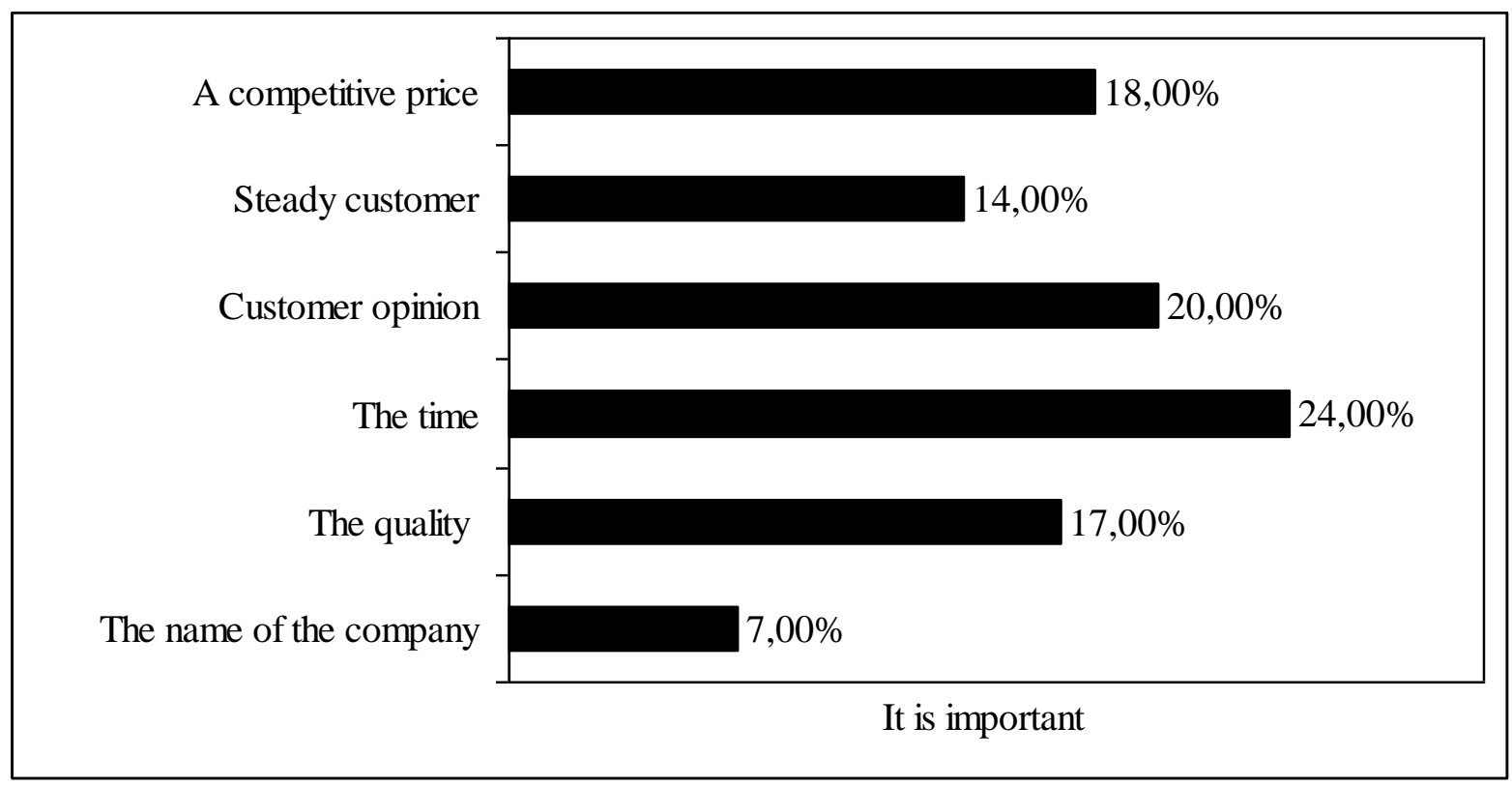

Figure 4 Transport company's success factors (Ginavičienė \& Sprogytė, 2015)

Taking into account the questioning on the performance of students as consumers, a competitiveness-enhancing factors model for a transport company (Fig. 5) can be provided. The most important role is played by analyses of competitors and evaluations of customer satisfaction, which are the criteria allowing the transport company's management to evaluate performance enhancement and to provide these success factors.

In summary, the investigation suggests that the Lithuanian transport companies are aware that in order to remain competitive, they must analyze customer feedback, evaluate it and provide services on demand.

Comparing the activities of competitors, the respondents said that their company continued to adhere to the principles of work and took into account the clients' wishes, complaints and responded to them. Students who participated in the study, identified quality of work, timeliness, competitive price and stable customer base as the main success factors. For the competitiveness enhancement, the respondents suggested the transport companies to continually assess their customer satisfaction and analyze the competitors' activities. 


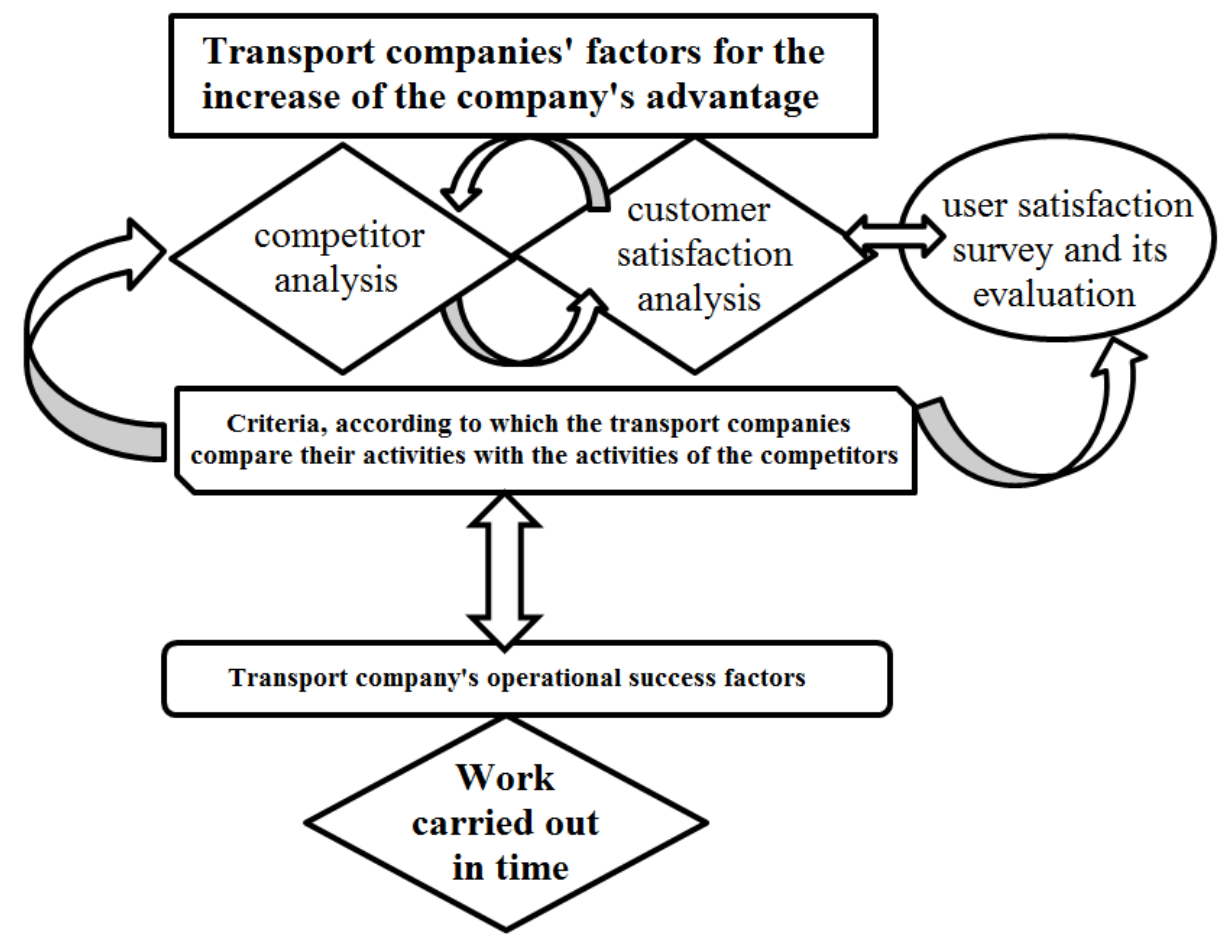

Figure 5 Competitive advantage model for transport companies

(Ginavičienė \&Sprogytė, 2015)

\section{Conclusions}

The authors of this paper investigated the competitiveness indicators used by Lithuanian transport companies in students' opinion. The result of the empirical research showed that the most important factors were suppliers, competitors and customers in the Lithuanian transport companies.

The students' opinion research showed that the customer satisfaction evaluated, the competitors' activities analyzed and quality management systems introduced were the factors applied by the Lithuania transport companies in increasing their advantage.

Under the contemporary global market conditions, meeting the consumer needs is mandatory. This is confirmed by the results of empirical research on students' opinions. The survey showed that the Lithuanian transport companies, being in competition with each other and in comparing their own activities, indicated that carrying out the works on time and taking into account the customers' wishes and responses were the main factors of the competitive advantage. 


\section{References}

Balcarová, P. (2014). The Comparison of nine-factor model and diamond model: Application for the Czech Republic, Slovakia and Hungary. Acta academica karviniensia. v. XIV, $n$. $1,5-15$.

Bivainis, J., \& Zinkevičiūte, V. (2006). Reasoning of business strategic decisions selection. Ūkio Technologinis ir Ekonominis Vystymas, v. XII, n.2, 99-107.

Cyplik P., Głowacka D. \& Fertsch M., (2008), Logistyka przedsiębiorstw dystrybucyjnych, Wyższa Szkoła Logistyki, Poznań.

Čiburiené, J. (2009). The innovativeness of SME activity in the context of globalization in Lithuania. Ekonomika ir vadyba, n. 14, 723-730. Downloaded from http://etalpykla.lituanistikadb.lt/fedora/get/LT-LDB-0001:J.04 2009 1367168412429/ DS.002.1.01.ARTIC

Dudzevičiūtè, G., \& Peleckienè, V. (2010). Marketing strategy process: quantitative analysis of the customers' satisfaction. Business: theory and practice, $v$. XI, n. 4, 345-352.

Yaya, P., H., L., \& Marimon, F., \& Casadesus, M. (2014). The revitalising effect of ISO 9001 on dissatisfied customers. Total Quality Management \& Business Excellence, $v$. 25, n. 8, 856-864. Downloaded from http://dx.doi.org/10.1080/14783363.2014.904567

Karaliūtè, E., \& Pilelienè, L. (2012). Vartotojų pasitenkinimo autoserviso paslaugomis. Management theory and studies for rural business and infrastructure development, $v$. 33, n. 4, 51-58. Downloaded from http://mts.asu.lt/mtsrbid/article/viewFile/170/199

Keršienè, R. (2009). Konkurencingumo išsaugojimo veiksniai globalizacijos sąlygomis. Ekonomika ir vadyba, n. 14, 819 - 824.

Mickevičienè, M. (2011). Imonès kompetencijos kaip tvaraus konkurencinio pranašumo kūrimo intrumentas: strateginis iššūkis. Business Systems and Economics, v.1, n.1, 8-22.

Mitkute, G., \& Nagreckaite, L. (2005). Konkurencingumo tyrimo modeliu analizé.

Downloaded from

http://www.ebiblioteka.lt/resursai/Konferencijos/KTU_PI/KNYGA2005\%20PDF/straip sniai/Plenarinis/Mitkute,\%20Nagreckaite.pdf.

Nabavi, V., Azizi, M., \& Faezipour, M. (2014). Implementation of quality management system based on ISO9001:2008 and its effects on customer satisfaction case study. International Journal of Quality \& Reliability Management, v. 31, n.8, 921 - 937.

Nedelescu-Ionescu, D., \& Rujan, O. (2014). Why do logistics and transport matter for development. Annals of the University of Oradea : Economics Sciences, Tom XXII , $v$. 1, 34-39, july. 2014. Downloaded from http://www.socert.usv.ro/fisiere/ 1409927152P67.pdf

Pajuodis, A. (2005). Prekybos marketingas. Vilnius: Eugrimas.

Palšaitis, R. (2010). Šiuolaikine logistika: mokomoji knyga. Vilnius: Technika.

Pérez, A., M. del Mar García de los Salmones, M., \& Rodríguez del Bosque, I., (2013). The effect of corporate associations on consumer behaviour. European Journal of Marketing, v. 47, $218-238$.

Ragelskaja, E., \& Korsakienè, R. (2011). Integruotas požiūris ì konkurencini pranašumą. Verslas XXI amžiujel Business in XXI Century, n. 3 (4), 70-75. Downloaded from http://www.mla.vgtu.lt/index.php/mla/article/viewFile/mla.2011.072/pdf_1

Svedaite, E., \& Ambras, A. (2013). Student Practice Integration into Temporary Employment Services. Socialiniai tyrimai/ Social Research, n. 4 (33), 36-43.

Valackienè, A. (2004). Sociologinis tyrimas:vadovèlis. Kaunas :Technologija. 
Jurgita Ginavičiene, Indre Sprogytè. Competitiveness of Transport Companies in the Opinion of

Vidaus reikalu ministerija (2010). European Consumer Satisfaction Management Guide. Downloaded from http://vakokybe.vrm.lt/index.php?id=525

Virvilaite, R. (2012). Marketingo valdymas. Kaunas: Technologija.

Zikienė, K., \& Brazinskaitė, V. (2012). Asmeninių charakteristiku itakos vartotojų lojalumo formavimuisi nustatymas. Organizaciju vadyba: sisteminiai tyrimai , n. 63, 113- 124.

Wyrwicka, M. K., Kliber, M. C., \& Brzeziński, Ł. (2015). Effects of promotional campaign in the logistics customer service. Research in Logistics \& Production, v. 5, n. 4, 407-416. 